\title{
Traces of the Ramayana and Mahabharata in Javanese and Malay Literature
}




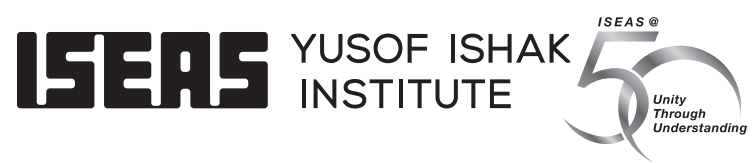

The ISEAS - Yusof Ishak Institute (formerly Institute of Southeast Asian Studies) is an autonomous organization established in 1968. It is a regional centre dedicated to the study of socio-political, security, and economic trends and developments in Southeast Asia and its wider geostrategic and economic environment. The Institute's research programmes are grouped under Regional Economic Studies (RES), Regional Strategic and Political Studies (RSPS), and Regional Social and Cultural Studies (RSCS). The Institute is also home to the ASEAN Studies Centre (ASC), the Nalanda-Sriwijaya Centre (NSC), and the Singapore APEC Study Centre.

ISEAS Publishing, an established academic press, has issued more than 2,000 books and journals. It is the largest scholarly publisher of research about Southeast Asia from within the region. ISEAS Publishing works with many other academic and trade publishers and distributors to disseminate important research and analyses from and about Southeast Asia to the rest of the world. 


\title{
Traces of the
}

\section{Ramayana and Mahabharata} in Javanese

\section{and Malay} Literature

\author{
EDITED BY \\ DING CHOO MING \\ WILLEM VAN DER MOLEN
}


First published in Singapore in 2018 by

ISEAS Publishing

30 Heng Mui Keng Terrace

Singapore 119614

E-mail:publish@iseas.edu.sg

Website: bookshop.iseas.edu.sg

All rights reserved. No part of this publication may be reproduced, stored in a retrieval system, or transmitted in any form or by any means, electronic, mechanical, photocopying, recording or otherwise, without the prior permission of the ISEAS - Yusof Ishak Institute.

(C) 2018 ISEAS - Yusof Ishak Institute, Singapore

The responsibility for facts and opinions in this publication rests exclusively with the authors and their interpretations do not necessarily reflect the views or the policy of the publisher or its supporters.

\section{ISEAS Library Cataloguing-in-Publication Data}

Traces of the Ramayana and Mahabharata in Javanese and Malay Literature / edited by Ding Choo Ming and Willem van der Molen.

1. Vālmīki. Rāmāyaṇa.

2. Mahābhārata.

3. Malay literature.

4. Javanese literature.

I. Ding, Choo Ming.

II. Molen, W. van der (Willem), 1952-

PL5170 T75 2018

ISBN 978-981-4786-57-7 (soft cover)

ISBN 978-981-4786-58-4 (E-book PDF)

Cover illustration: wooden statue of a scribe. Collectie Stichting Nationaal Museum van Wereldculturen. Coll. nr. TM-809-112.

Typeset by International Typesetters Pte Ltd

Printed in Singapore by Mainland Press Pte Ltd 